\title{
Residual frying oil in the diets of sheep: intake, digestibility, nitrogen balance and ruminal parameters
}

\author{
Eduardo Lucas Terra Peixoto ${ }^{1, *}$, Ivone Yurika Mizubuti ${ }^{2}$, Edson Luiz de Azambuja Ribeiro², \\ Elizabeth dos Santos Moura², Elzânia Sales Pereira ${ }^{3}$, Odimari Pricila Pires do Prado², \\ Larissa Nóbrega de Carvalho², and Kássia Amariz Pires ${ }^{2}$
}

\footnotetext{
* Corresponding Author: Eduardo Lucas Terra Peixoto Tel: +55-94-2110-7110

E-mail: eltpeixoto@unifesspa.edu.br

${ }^{1}$ Faculty of Agricultural Sciences, Federal University of South and Southeast of Pará, Marabá, PA, CEP 68555-907, Brazil

${ }^{2}$ Department of Animal Science, State University of Londrina, Londrina, PR, CEP 86.057-970, Brazil

3 Department of Animal Science, Federal University of

Ceará, Fortaleza, CE, CEP 60021-970, Brazil
}

Submitted Nov 26, 2015; Revised Jan 6, 2016; Accepted Feb 11, 2016
Objective: The objective of this study was to evaluate the intake and nutrient digestibility, nitrogen balance and ruminal ammonia nitrogen in lambs of diets containing different levels of residual frying oil.

Methods: Levels of 0, 20, 40, 60, and $80 \mathrm{~g} / \mathrm{kg}$ dry matter (DM) base of residual frying oil in the diets of lambs were evaluated. Five castrated lambs with initial body weights of $36.8 \pm 3.3 \mathrm{~kg}$, distributed in a Latin square $(5 \times 5)$ design, were used.

Results: There was a decreasing linear effect on the intake of DM, organic matter (OM), crude protein $(\mathrm{CP})$, neutral detergent fiber (NDF), total carbohydrates (TCH), and nonfibrous carbohydrates (NFC). There was an increased linear intake of ether extract (EE). The apparent digestibility of DM, OM, CP, NDF, TCH, and NFC, as well as urine nitrogen excretion, nitrogen balance and ruminal parameters, were not influenced by different levels of residual frying oil in the diet. EE digestibility presented a crescent linear effect.

Conclusion: It can be concluded that the addition of residual frying oil to the diets of sheep can affect nutrient intake without affecting the digestibility of most nutrients (with the exception of EE), nitrogen balance and ruminal ammonia nitrogen concentration.

Keywords: Alternative Feed, Byproduct, Feedstuff Energetic, Lambs, Lipid Source

\section{INTRODUCTION}

Lipids are organic compounds that are composed of fat or oils; are soluble in organic solvents such as benzene, ether or chloroform; and are insoluble in water. Although the total amount of lipid in the diet of ruminants is less than $5 \%$, lipids have a very important role in the energy metabolism of the animals because they are made up of a high proportion of fatty acids. Lipids have 2.25 times more energy than carbohydrates, and therefore, are considered a high concentration of quickly available energy [1].

An alternative lipid source, residual vegetable oil from the frying process, in contrast to other surplus food, is slowly degraded in the environment, and its disposal becomes an environmental, social and economic problem. Residual frying oil (RFO) can be repurposed for the manufacture of soap and biodiesel. However, a more attractive alternative would be its inclusion in animal feed because the residue can be converted into food and into a source of income while also reducing the damaging effects of $\mathrm{RFO}$ on the environment.

Another important aspect of residue oil usage in feeds is that the addition of lipids to ruminant feed frequently improves the feed-conversion efficiency; in other words, diets containing fat may require a lower dry matter intake for body weight gain [2]. 
On the other hand, the inclusion of lipids at levels greater than $5 \%$ of the dry matter (DM) in ruminant diets is related to changes in rumen fermentation [3]. However, this value varies, depending on the digestibility of each fat source, and the degree of unsaturation is the factor that most affects fatty acid digestibility.

The objective of this study was to evaluate the intake, nutrient digestibility, nitrogen balance, and ruminal ammonia nitrogen in lambs with diets containing different levels of RFO.

\section{MATERIAL AND METHODS}

\section{Study location}

The experiment was carried out at the ruminant metabolism sector of the farm school of the Londrina State University, Paraná, Brazil. Analyses of the collected materials were carried out at the Animal Nutrition Laboratory of the Londrina State University, Brazil. All protocols for the research have been approved by the Animal Ethics Committee at the same institution under register number CEUA 46/12 process 28732/11.

\section{Animals housing and feeding}

Inclusion levels of $0,20,40,60$, and $80 \mathrm{~g} / \mathrm{kg}$ DM base of RFO in diets for lambs were evaluated. Diets were formulated to be isonitrogenous (Table 1) and were increased by $10 \%$ to the requirements according to the NRC [4]. All diets were kept at a forage:concentrate ratio of 60:40, where the source of forage was sorghum silage and the concentrate ration sources were, corn, wheat bran, soybean meal, a vitamin and mineral mixture, and RFO (Table 1).

The residual frying oil was obtained from the company BEM
AMBIENTAL enterprise which captures oils residuals in Londrina-PR and region. The residual frying oil was stored in dark plastic drums with 20 L capacity, without the addition of antioxidant. The collected product is a mixture of oil from different vegetable sources and distincts origins such as restaurants, coffee shops, snack bar and bakeries. It had dark brown color with a strong odor of rancid due to oxidation process.

Five castrated lambs of undefined breed with initial body weights of $36.8 \pm 3.3 \mathrm{~kg}$ were used. The animals were kept in cages with individual feeders and waterers for the metabolism trial. For total feces collection, collector bags were used. The animals were weighed at the beginning and end of each evaluation period for adjustment of diets. Each trial period lasted 15 days, the first ten days were for diet adaptation. Experimental animals were submitted to the pre-experimental period (15 days) for adaptation to the metabolism cage, routine handling and feeding. Diets were given as a whole mixture twice a day at 7 am and 4 pm to minimize feed loss by animals.

\section{Sampling and analysis of feed, orts, and feces}

The weighing of food offered and orts was performed daily, and data collected regarding the feeding portions for each animal during each trial period were later analyzed. Offered food and orts, as well as feces and urine, were sampled from the 11th up to 14 th day of each trial period to determine intake, nutrient digestibility and nitrogen balance. Solid samples (supplied diet, orts and feces) were placed in plastic bags, identified, and frozen at a temperature of $-18^{\circ} \mathrm{C}$ immediately after collection. At the end of the experimental period, the samples were defrosted and dried in forced air ovens at a temperature of $55^{\circ} \mathrm{C}$ for 72

Table 1. Food and chemical compositions in dry matter basis of diets containing different levels of residual frying oil for lambs

\begin{tabular}{|c|c|c|c|c|c|}
\hline \multirow{2}{*}{ Feed } & \multicolumn{5}{|c|}{ Levels of residual frying oil (g/kg DM) } \\
\hline & 0 & 20 & 40 & 60 & 80 \\
\hline Sorghum silage (g/kg DM) & 600.0 & 600.0 & 600.0 & 600.0 & 600.0 \\
\hline Corn (g/kg DM) & 189.4 & 171.0 & 152.7 & 134.3 & 116.0 \\
\hline Wheat bran (g/kg DM) & 81.2 & 73.3 & 65.4 & 57.6 & 49.7 \\
\hline Soybean meal (g/kg DM) & 109.4 & 115.6 & 121.9 & 128.1 & 134.3 \\
\hline Mix mineral vitamin (g/kg DM) & 20.0 & 20.0 & 20.0 & 20.0 & 20.0 \\
\hline Residual oil frying (g/kg DM) & 0.0 & 20.0 & 40.0 & 60.0 & 80.0 \\
\hline Total & $1,000.0$ & $1,000.0$ & $1,000.0$ & $1,000.0$ & $1,000.0$ \\
\hline \multicolumn{6}{|l|}{ Chemical composition of diets } \\
\hline Dry matter (g/kg) & 494.5 & 497.5 & 500.6 & 503.6 & 506.7 \\
\hline Organic matter (g/kg DM) & 933.1 & 933.3 & 933.5 & 933.8 & 934.0 \\
\hline Crude protein (g/kg DM) & 128.2 & 128.3 & 128.4 & 128.5 & 128.5 \\
\hline Ether extract (g/kg DM) & 26.0 & 44.8 & 63.6 & 82.4 & 101.2 \\
\hline NDF (g/kg DM) & 523.8 & 517.6 & 511.5 & 505.3 & 499.1 \\
\hline ADF (g/kg DM) & 265.7 & 260.8 & 255.8 & 250.8 & 245.8 \\
\hline Lignin (g/kg DM) & 39.4 & 39.2 & 39.0 & 38.8 & 38.6 \\
\hline Cellulose (g/kg DM) & 202.3 & 201.5 & 200.7 & 200.0 & 199.2 \\
\hline TCH (g/kg DM) & 778.8 & 760.2 & 741.5 & 722.8 & 704.1 \\
\hline NFC (g/kg DM) & 264.4 & 251.7 & 239.1 & 226.4 & 213.7 \\
\hline
\end{tabular}

DM, dry matter; NDF, neutral detergent fiber; ADF, acid detergent fiber; TCH, total carbohydrates; NFC, no-fibrous carbohydrates. 
hours. Subsequently, they were milled in a Willey-type mill with a sieve of $1 \mathrm{~mm}$.

Chemical composition was identified using the methodology described by Mizubuti et al [5] for determining the content of $\mathrm{DM}$, crude protein (CP), ether extract (EE), ash, neutral detergent fiber (NDF), acid detergent fiber, and lignin. Total carbohydrates $(\mathrm{TCH})$ contents were calculated according to the equation proposed by Sniffen et al [6]: \% TCH $=100-(\% \mathrm{CP}+\% \mathrm{EE}+\%$ ash $)$. The nonfibrous carbohydrate (NFC) content was calculated using the difference between \% $\mathrm{TCH}$ and \%NDF.

The direct method was used to determine the apparent digestibility (AD) of nutrients by evaluating the nutrient content in feed samples and feces. The $\mathrm{AD}$ was obtained using the equation described by Coelho da Silva and Leão [7]:

$$
\mathrm{AD}=[(\mathrm{Nf}-\mathrm{No}-\mathrm{Nfc}) /(\mathrm{Nf}-\mathrm{No})] \times 100,
$$

Where, $\mathrm{Nf}=$ nutrient in feed $(\mathrm{g}), \mathrm{No}=$ nutrient in orts $(\mathrm{g})$, and $\mathrm{Nfc}=$ nutrient in feces $(\mathrm{g})$.

The total digestible nutrient (TDN) content of feedstuffs and diets were estimated according to the equation described by Sniffen et al [6]:

\section{$\mathrm{TDN}=\mathrm{DCP}+2.25 \mathrm{DEE}+\mathrm{DTCH}$}

Where, $\mathrm{DCP}=$ digestible crude protein, $\mathrm{DEE}=$ digestible ether extract, and DTCH = digestible total carbohydrates.

\section{Sampling and analysis of urine}

For urine collection, $25 \mathrm{~mL}$ of 1:1 of 50\% (wt/wt) solution of $95 \% \mathrm{HCl}$ and water was placed in the collection containers daily between 11 and 14 days in each experimental period to prevent fermentation and ammonia losses in the urine by volatilization The total volume of urine excreted per animal was measured at intervals of 24 hours, and an aliquot corresponding to $10 \%$ of the total volume per animal was stored at $-15^{\circ} \mathrm{C}$ for later composition analysis. Nitrogen balance was calculated as the difference between the total nitrogen intake and the total nitrogen excreted in feces and urine [8], which were expressed in $\mathrm{g} / \mathrm{d}, \mathrm{g} / \mathrm{kg} \mathrm{BW}$ and $\mathrm{g} / \mathrm{kg}$ of $\mathrm{N}_{\text {intake }}$, respectively.

\section{Sampling and analysis of rumen liquor}

The rumen fluid was collected on the last day (15th day) of each experimental at 3 and 6 hours after de morning feeding [9] using an esophageal silicone probe connected to a vacuum pump. Approximately $100 \mathrm{~mL}$ of rumen fluid were collected from each animal. Afterwards, samples were filtered through three layers of cheesecloth, and three aliquots of $20 \mathrm{~mL}$ were taken from each sample. These samples were packed in pots containing sixteen drops of sulfuric acid ( $50 \% \mathrm{wt} / \mathrm{wt})$ solution of $98 \%$ sulfuric acid and water and were stored at $-18^{\circ} \mathrm{C}$ for determination of the ruminal ammonia concentration $\left(\mathrm{NH}_{3}-\mathrm{N}\right)$.
$\mathrm{NH}_{3}-\mathrm{N}$ concentrations in the rumen fluid samples were determined by distillation with potassium hydroxide $(2 \mathrm{~N})$, according to a technique described by Preston [10].

\section{Statistical analysis}

The experimental design was a Latin square design $(5 \times 5)$ with five levels of RFO, five periods of sampling and five animals (experimental units). Data were submitted to a normality test for distribution of errors, to a homogeneity of variance test, and subsequently, to an analysis of variance $(\alpha=0.05)$. The statistical package $\mathrm{R}$ [11] was used to study the mean values by regression analysis, using "F" test $(\alpha=0.05)$.

\section{RESULTS AND DISCUSSION}

\section{Nutrients intake}

There was a linear decreasing effect on DM, organic matter $(\mathrm{OM})$, $\mathrm{CP}, \mathrm{NDF}, \mathrm{TCH}$, and NFC intake when expressed in $\mathrm{g} / \mathrm{d} / \mathrm{animal}$ (Table 2).

A reduction in the intake of these components was most likely due to the high intake of EE that increased linearly $(\mathrm{p}<0.05)$ when expressed in the same unit. In this study, the levels of lipids in the diet with greater levels of RFO $(40,60$, and $80 \mathrm{~g} / \mathrm{kg} \mathrm{DM})$ exceeded the maximum level of $\mathrm{EE}$ recommended by the Palmquist and Mattos [12]: That is, $50 \mathrm{~g} / \mathrm{kg}$ in the total diet. According to these authors, levels above $50 \mathrm{~g} / \mathrm{kg}$ in the diet may negatively affect nutrient intake, either by affecting the regulatory mechanisms that control food intake or by limiting the capacity of the ruminants to oxidize fatty acids. Another aspect that could explain a reduction in intake $(\mathrm{g} / \mathrm{d})$ of the components NDF, $\mathrm{TCH}$, and NFC is a reduction in the levels of these components in the diet (Table 1).

The CP intake, when expressed in $\mathrm{g} / \mathrm{d}$ for RFO levels of 60 and $80 \mathrm{~g} / \mathrm{kg}$ of DM, was not able to fulfill the requirements proposed by the NRC [4], which is $160 \mathrm{~g}$ for lambs that are eight months old and weigh $40 \mathrm{~kg}$. Dry matter intake was also lower than that estimated by the NRC [4] when expressed in $\mathrm{kg} / \mathrm{d}$ (1.39) and $\mathrm{g} / \mathrm{kg} \mathrm{BW}$ (32.5) for the same category at all levels of inclusion of RFO. The NDF intake, when expressed in $\mathrm{g} / \mathrm{kg} \mathrm{BW}$, was within the limits needed for the rumen to function as reported by Van Soest [13]: That is, 8 to $12 \mathrm{~g} / \mathrm{kg}$ BW.

The intake of all the nutritional components, when expressed in $\mathrm{g} / \mathrm{kg} \mathrm{BW}$ and $\mathrm{g} / \mathrm{kg} \mathrm{BW}{ }^{0.75}$, was not affected by the different levels of RFO in the diet (Table 2). This could be due to the experimental design because all animals were fed all diets at different moments. Therefore, it could be that the body weight of the animals influenced the nutrient intake, keeping them at balance. Another aspect that may have contributed to this effect is the variation in intake behavior of the animals according to their individual acceptance of the diets. According to Forbes [14], acceptability is not only a characteristic of the food but should also be observed as a function of the animal, with likes 
Table 2. Means, regression equations, regression coefficients, and variance coefficients for nutrient intake of diets for lambs with different levels of residual frying oil

\begin{tabular}{|c|c|c|c|c|c|c|c|c|c|}
\hline \multirow{2}{*}{ Items } & \multicolumn{5}{|c|}{ Levels of residual frying oil (g/kg DM) } & \multirow{2}{*}{ Regression } & \multirow{2}{*}{$\mathbf{R}^{2}$} & \multirow{2}{*}{ CV (\%) } & \multirow{2}{*}{ p-value } \\
\hline & 0 & 20 & 40 & 60 & 80 & & & & \\
\hline \multicolumn{10}{|c|}{ Intake g/d } \\
\hline DM & $1,244.4$ & $1,122.6$ & $1,152.3$ & $1,093.8$ & 981.9 & $\hat{Y}=1,229.7-27.7 x$ & 0.84 & 8.7 & ** \\
\hline $\mathrm{OM}$ & $1,125.9$ & $1,019.2$ & $1,072.2$ & 985.7 & 880.3 & $\hat{Y}=1,121.6-26.2 x$ & 0.80 & 9.0 & ** \\
\hline$C P$ & 170.6 & 155.9 & 165.1 & 150.2 & 140.5 & $\hat{Y}=169.7-3.3 x$ & 0.76 & 9.1 & * \\
\hline $\mathrm{EE}$ & 36.1 & 60.1 & 87.7 & 110.3 & 124.6 & $\hat{Y}=38.3+11.4 x$ & 0.99 & 10.8 & ** \\
\hline NDF & 565.6 & 481.8 & 510.6 & 460.7 & 394.8 & $\hat{Y}=555.3-18.1 x$ & 0.83 & 12.0 & ** \\
\hline $\mathrm{TCH}$ & 919.2 & 803.2 & 819.5 & 725.2 & 615.2 & $\hat{Y}=913.6-34.3 x$ & 0.91 & 9.3 & ** \\
\hline NFC & 353.5 & 321.4 & 308.9 & 264.4 & 220.4 & $\hat{Y}=358.4-16.2$ & 0.97 & 8.8 & ** \\
\hline TDN & 715.2 & 762.4 & 754.5 & 742.2 & 627.2 & $\hat{Y}=720.3$ & - & 15.9 & ns \\
\hline \multicolumn{10}{|c|}{ Intake g/kg body weight } \\
\hline $\mathrm{DM}$ & 28.2 & 26.3 & 25.4 & 25.2 & 25.1 & $\hat{Y}=26.0$ & - & 11.5 & ns \\
\hline $\mathrm{OM}$ & 25.4 & 23.6 & 23.0 & 22.7 & 23.3 & $\hat{\mathrm{Y}}=23.6$ & - & 10.7 & ns \\
\hline$C P$ & 3.9 & 3.7 & 3.5 & 3.5 & 3.6 & $\hat{Y}=3.6$ & - & 10.7 & ns \\
\hline $\mathrm{EE}$ & 2.0 & 1.9 & 1.9 & 1.7 & 1.8 & $\hat{Y}=1.9$ & - & 10.9 & ns \\
\hline NDF & 12.3 & 11.1 & 10.5 & 11.1 & 11.2 & $\hat{Y}=11.2$ & - & 12.7 & ns \\
\hline $\mathrm{TCH}$ & 19.5 & 18.0 & 17.7 & 17.5 & 17.8 & $\hat{Y}=18.1$ & - & 11.2 & ns \\
\hline NFC & 7.2 & 6.8 & 7.1 & 6.4 & 6.6 & $\hat{\mathrm{Y}}=6.8$ & - & 10.4 & ns \\
\hline TDN & 18.5 & 18.6 & 17.2 & 16.0 & 13.0 & $\hat{\mathrm{Y}}=16.6$ & - & 17.9 & ns \\
\hline \multicolumn{10}{|c|}{ Intake g/kg body weight 0.75} \\
\hline DM & 71.9 & 67.3 & 65.3 & 64.7 & 64.00 & $\hat{Y}=66.6$ & - & 11.4 & ns \\
\hline $\mathrm{OM}$ & 64.8 & 60.5 & 59.1 & 58.3 & 59.4 & $\hat{\mathrm{Y}}=60.4$ & - & 10.6 & ns \\
\hline$C P$ & 10.00 & 9.5 & 8.9 & 9.00 & 9.1 & $\hat{Y}=9.3$ & - & 10.7 & ns \\
\hline EE & 5.1 & 5.00 & 4.8 & 4.5 & 4.8 & $\hat{Y}=4.8$ & - & 10.9 & ns \\
\hline NDF & 31.5 & 28.4 & 27.00 & 28.3 & 28.6 & $\hat{\mathrm{Y}}=28.8$ & - & 12.6 & ns \\
\hline $\mathrm{TCH}$ & 49.7 & 46.00 & 45.3 & 44.8 & 45.5 & $\hat{Y}=46.3$ & - & 11.1 & ns \\
\hline NFC & 18.2 & 17.5 & 18.3 & 16.4 & 17.00 & $\hat{Y}=17.5$ & - & 10.3 & ns \\
\hline TDN & 46.0 & 47.0 & 44.2 & 41.7 & 34.3 & $\hat{\mathrm{Y}}=42.6$ & - & 17.35 & ns \\
\hline
\end{tabular}

$\mathrm{CV}$, coefficient variation; DM, dry matter; OM, organic matter; $\mathrm{CP}$, crude protein; $\mathrm{EE}$, ether extract; NDF, neutral detergent fiber; TCH, total carbohydrates; NFC, non-fibrous cabohydrates; TDN, total nutrients digestible; ns, no significant.

**** Significant at $5 \%$ and $1 \%$ probability, respectively.

and dislikes for certain foods.

The different levels of RFO were not able to promote an effect (Table 2) on the TDN intake, regardless of the form expressed, even with the significant increase in EE intake, which is the more energetic fractional component of this variable. A similar effect was observed by Nunes et al [15], who evaluated the nutrient intake of lambs from diets containing different levels of palm kernel cake. The recommended intake of this component, as recommended by the NRC [4], is $860 \mathrm{~g} / \mathrm{d}$.

\section{Nutrients digestibility}

The digestibility of DM, OM, CP, NDF, TCH, and NFC was not influenced by the addition of RFO on the diet (Table 3). These results corroborate the results obtained by Bateman II

Table 3. Nutrients digestibility of diets of lambs containing different levels of residual oil frying

\begin{tabular}{|c|c|c|c|c|c|c|c|c|c|}
\hline \multirow{2}{*}{ Variable } & \multicolumn{5}{|c|}{ Levels of residual frying oil (g/kg DM) } & \multirow{2}{*}{ Regression } & \multirow{2}{*}{$\mathrm{R}^{2}$} & \multirow{2}{*}{ CV (\%) } & \multirow{2}{*}{ p-value } \\
\hline & 0 & 20 & 40 & 60 & 80 & & & & \\
\hline DM & 0.58 & 0.58 & 0.57 & 0.62 & 0.52 & $\hat{Y}=0.57$ & - & 8.78 & ns \\
\hline $\mathrm{OM}$ & 0.59 & 0.58 & 0.59 & 0.61 & 0.50 & $\hat{Y}=0.57$ & - & 10.43 & ns \\
\hline $\mathrm{CP}$ & 0.59 & 0.60 & 0.61 & 0.64 & 0.59 & $\hat{Y}=0.61$ & - & 8.98 & ns \\
\hline $\mathrm{EE}$ & 0.86 & 0.89 & 0.93 & 0.94 & 0.94 & $\hat{Y}=0.87+0.01 x$ & 0.83 & 2.97 & ** \\
\hline NDF & 0.42 & 0.39 & 0.39 & 0.40 & 0.29 & $\hat{\mathrm{Y}}=0.38$ & - & 23.39 & ns \\
\hline TCH & 0.58 & 0.55 & 0.55 & 0.55 & 0.47 & $\hat{Y}=0.54$ & - & 9.71 & ns \\
\hline NFC & 0.83 & 0.84 & 0.79 & 0.80 & 0.79 & $\hat{Y}=0.81$ & - & 9.54 & ns \\
\hline
\end{tabular}

DM, dry matter; $C V$, coefficient variation; OM, organic matter; $C P$, crude protein; EE, ether extract; NDF, neutral detergent fiber; TCH, total carbohydrates; NFC, non-fibrous carbohydrates; ns, no significant.

*, ** Significant at $5 \%$ and $1 \%$ probability, respectively. 
and Jenkins [16] and Pimentel et al [17], who did not observe any effects of lipid inclusion in the ration on apparent digestibility of these nutrients, suggesting that significant amounts of unprotected lipids may be added to the rations because they do not affect nutrient digestibility.

However, the EE digestibility exhibited crescent linear behavior (Table 3). This can be explained by higher fat digestibility. Another possibility would be the presence of higher levels of $\mathrm{EE}$ in the diet, which can cause higher digestibility of this fraction. According to the NRC [17], the digestibility of fatty acid, a component of EE, can be influenced by dry matter intake, by the amount consumed, and by the characteristics of dietary lipids. The degree of unsaturation is perhaps the feature that most influences lipid digestion. Therefore, an optimal source of lipids for ruminants would be one that does not interfere with the digestibility of other nutrients and that produces high intestinal digestibility.

\section{Nitrogen balance}

Urine excretion and nitrogen retention were not influenced by the levels of RFO (Table 4). All diets resulted in positive nitrogen retention, with an average $6.4 \mathrm{~g} \mathrm{~N}$ retained per day, the equivalent of $22.24 \%$ of nitrogen intake. In this work, the nitrogen lost in urine $368.7 \mathrm{~g} / \mathrm{kg} \mathrm{N} \mathrm{N}_{\text {intake }}$ was higher than that found by Zeoula et al [9] of $309.0 \mathrm{~g} / \mathrm{kg} \mathrm{N}_{\text {intake, }}$, difference that can be explained by the higher content of dietary CP: $12.8 \%$ vs $10.9 \%$. However, our results were similar to those reported by Alves et al [18], who found a mean value of $376.5 \mathrm{~g} / \mathrm{kg} \mathrm{N} \mathrm{N}_{\text {intake}}$, which is similar to the $\mathrm{CP}$ concentration in the diets.

A negative linear effect was observed for the nitrogen intake and nitrogen excretion in the feces when expressed in $\mathrm{g} / \mathrm{d}$ (Table 4). The reduction in nitrogen excretion in feces is due to the reduction in the intake of this nutrient (Table 2). However, when expressed as a function of nitrogen intake, nitrogen excretion was not affected by the levels of RFO. The N excretion in the feces was higher than in the urine. Zeoula et al [9], used diets with $10.9 \% \mathrm{CP}$ and found lower $\mathrm{N}$ excretion through the urine ( $\left.309 \mathrm{~g} / \mathrm{kg} \mathrm{N}_{\text {intake }}\right)$ in relation to the fecal excretion ( $\left.352 \mathrm{~g} / \mathrm{kg} \mathrm{N}_{\text {intake }}\right)$, similar to what occurred in this work. They provided diets that contained different levels of cassava meal to replace corn and soybean meal as a protein source for sheep. According to Hristov et al [19], improved use of ammonia in the rumen can transfer nitrogen excretion from the urine to the feces.

\section{Ruminal ammonia nitrogen}

The concentration of ruminal ammonia nitrogen $\left(\mathrm{NH}_{3}-\mathrm{N}\right)$ was not affected by the diets containing RFO; additionally, there was no interaction between diet and the collection time (Table 4). The ruminal ammonia concentration may be indicative of the fermentation of amino acids and may indicate high levels of rumen-degraded protein and reduced levels of NFC in the rumen. Thus, no change was observed in the concentrations of $\mathrm{NH}_{3}-\mathrm{N}$, showing that lipids in the diet from the addition of RFO does not promote a depressant effect on the population of Gram-positive bacteria, which ferment obligatory amino acids to meet their energy and protein needs [20]. The concentrations of $\mathrm{NH}_{3}-\mathrm{N}$ were higher than the range considered optimal (15 to $29 \mathrm{mg} / \mathrm{dL}$ ) for achieving maximum microbial fermentation in ruminants without negatively influencing fiber degradation [21].

\section{CONCLUSION}

The addition of RFO to the diets of sheep can affect nutrient intake without affecting the digestibility of most nutrients (with the exception of EE), the nitrogen balance and the ruminal ammonia nitrogen concentration. However, studies evaluating the performance and economic viability of lambs feed whit residual frying oil is necessary.

Table 4. Intake, excretion, nitrogen balance and ruminal ammonia nitrogen of lambs fed diets with different levels of residual frying oil

\begin{tabular}{|c|c|c|c|c|c|c|c|c|c|}
\hline \multirow{2}{*}{ Items } & \multicolumn{5}{|c|}{ Levels of residual frying oil (g/kg DM) } & \multirow{2}{*}{ Regression } & \multirow{2}{*}{$\mathbf{R}^{2}$} & \multirow{2}{*}{ CV (\%) } & \multirow{2}{*}{$\mathrm{p}$-value } \\
\hline & 0 & 20 & 40 & 60 & 80 & & & & \\
\hline \multicolumn{10}{|l|}{ N intake } \\
\hline \multicolumn{10}{|l|}{ Fecal N } \\
\hline $\mathrm{g} / \mathrm{d}$ & 11.09 & 9.93 & 10.17 & 8.38 & 8.67 & $\hat{Y}=10.93-0.32 x$ & 0.82 & 13.72 & * \\
\hline $\mathrm{g} / \mathrm{kg} \mathrm{N} \mathrm{N}_{\text {intake }}$ & 436.70 & 397.30 & 436.00 & 395.20 & 379.00 & $\hat{Y}=408.80$ & - & 18.82 & ns \\
\hline $\mathrm{g} / \mathrm{kg} \mathrm{N} \mathrm{N}_{\text {intake }}$ & 354.30 & 349.40 & 355.50 & 446.40 & 338.00 & $\hat{Y}=368.7$ & - & 20.77 & ns \\
\hline \multicolumn{10}{|l|}{$N$ retained } \\
\hline $\mathrm{g} / \mathrm{d}$ & 6.58 & 7.35 & 5.60 & 5.46 & 7.01 & $\hat{\mathrm{Y}}=6.40$ & - & 40.08 & ns \\
\hline $\mathrm{g} / \mathrm{kg} \mathrm{N}_{\text {intake }}$ & 209.00 & 253.30 & 208.50 & 158.30 & 283.00 & $\hat{\mathrm{Y}}=222.40$ & - & 54.53 & ns \\
\hline \multicolumn{10}{|l|}{ Ruminal fluid } \\
\hline
\end{tabular}

DM, dry matter; CV, variation coefficient; ns, no significant.

* Significant at $5 \%$ probability. 


\section{CONFLICT OF INTEREST}

We certify that there is no conflict of interest with any financial organization regarding the material discussed in the manuscript.

\section{ACKNOWLEDGMENTS}

The authors thank Conselho Nacional de Desenvolvimento Científico e Tecnológico (CNPq-Brazil) from Brazil for the financial support of the project.

\section{REFERENCES}

1. Silva MMC, Rodrigues MT, Branco RH, et al. Effects of fat supplements on intake and efficiency of nutrient utilization in lactating dairy goats. R Bras Zootec 2016;36:257-67.

2. Valinote AC, Nogueira Filho JCM, Leme PR, et al. Effects of feeding monensin and different sources of fat on the ruminal population of ciliate protozoa in Nellore steers. R Bras Zootec 2005;34:141823.

3. Cenkvari, E, Fekete S, Febel H, et al. Investigations on the effects of Ca-soap of linseed oil on rumen fermentation in sheep and on milk composition of goats. J Anim Physiol Anim Nutr 2005;89:172-8.

4. NRC (National Research Council). Nutrient Requirements of Small Ruminants: sheep, goats, cervids and new world camelids. Washington, DC: National Academies Press; 2007.

5. Mizubuti, IY, Pinto AP, Pereira ES, et al. Laboratory methods of feedstuff evaluation. Londrina, PR, Brazil: EDUEL- Editora da Universidade Estadual de Londrina; 2009.

6. Sniffen, CJ, O'Connor JD, Van Soest PJ, et al. A net carbohydrate and protein system for evaluating cattle diets: II. Carbohydrate and protein availability. J Anim Sci 1992;70:3562-77.

7. Coelho da Silva JF, Leão MI. Fundamentals of Ruminants Nutrition. Piracicaba, SP, Brazil: Livroceres; 1979.

8. Decandia M, Sitzia M, Cabiddu A, Kababya D, Molle G. The use of polyethylene glycol to reduce the anti-nutritional effects of tannins in goats fed woody species. Small Rumin Res 2000;38:157-64.

9. Zeoula LM, Caldas Neto SF, Geron LJV, et al. Cassava by-product flour replacing corn in ration for sheep: intake, digestibility, nitrogen and energy balances and ruminal parameters. R Bras Zootec 2003;
32:491-502

10. Preston, T R. Biological and chemical analytical methods. In: Preston TR, editor. Tropical Animal Feeding: A Manual for Research Workers. Rome, Italy: Food and Agriculture Organization of the United Nations; 1995. p. 191-264.

11. R. 2013. R: A language and environment for statistical computing. R Foundation for Statistical Computing, Vienna, Italy.

12. Palmquist DL, Mattos WRS. Metabolism of Lipids. In: Berchielli TT, Pires AV, Oliveira SG, editors. Ruminants Nutrition, Jaboticabal, SP, Brazil: FUNEP; 2006. p. 287-310.

13. Van Soest PJ. Nutrition eecology of the ruminant. 2nd ed. Ithaca, NY, USA: Comstock Publishing Associates; 1994.

14. Forbes JM. Natural feeding behavior and feed section. In: Heidde D, Huisman EA, Kanis E, Osse JMW, Verstegen M, editors. Regulation of Feed Intake. Wageningen, Netherlands: CAB International; 1999. p. 3-12.

15. Nunes AS, Oliveira RL, Borja MS, et al. Intake, digestibility and blood parameters of lambs fed diets with palm kernel. Archiv Zootec 2011; 60:903-12.

16. Bateman II HG, Jenkins TC. Influence of soybean oil in high fiber diets fed to nonlactating cows on ruminal unsaturated fatty acids and nutrient digestibility. J Dairy Sci 1998;81:2451-8.

17. Pimentel PG, Pereira ES, Queiroz AC, et al. Intake, apparent nutrient digestibility and ingestive behavior of sheep fed cashew nut meal. R. Bras Zootec 2011;40:1128-33.

18. Alves EM, Pedreira MS, Pereira MLA, et al. Mesquite pod meal associated with levels of urea on feeding sheep: Nitrogen balance, plasma urea-N and ruminal parameters. Acta Sci 2012;34:287-95.

19. Hristov AN, Ropp JK, Grandeen KL, et al. Effect of carbohydrate source on ammonia utilization in lactating dairy cows. J Anim Sci 2005;83:408-21.

20. Vargas LH, Lana RP, Jham GN, et al. Lipids in the ration of dairy cows: ruminal fermentation parameters, milk production and composition. R Bras Zootec 2002;31:522-9.

21. Preston TR. Analytical methods for characterizing. In: Preston TR, editor. Feed resourses for ruminants. better utilization of crop residues and by products in animal feeding: research guidelines. A Practical Manual for Research Workers. Rome, Italy: Food and Agriculture Organization of the United Nations; 1986. p. 99. 